\title{
Reconsidering governmental effects of grassland science and policy in China
}

\author{
Michael L. Zukosky ${ }^{1}$ \\ Eastern Washington University
}

In the spring of 2004, I sat talking with a few residents about grassland policy in a village of northwestern China's Altai Mountains. Many of the pastoral nomadic residents that I spoke with found my interest in the effects of grassland use policy on actual pastoral land use as absurd. At the most basic level, grassland use policy was supposed to have divided collective pastureland and distributed it to individual households. But as one resident named Umer said, "Most of the pastures were contracted out on paper, not in a physical sense." Another resident, rolling a cigarette in newspaper as he spoke, added that the "real change" from the collective period until the contemporary moment was; "on paper. It was a kind of writing. The reality of land use did not change." This was particularly interesting as the paper certificates issued to each household at decollectivization were supposed to index the household allocations of pasture that were provided to them. As he referred directly to the land use contract in his hand, another resident chimed in, "It has absolutely no use. It is only a kind of form" (K. forma, from Russian).

This example raises interesting questions about the governmental effects of grassland science and policy in China. While Peter Ho (2001) has argued that land tenure in China is mostly a "paper agreement" because governmental agencies can reappropriate and redistribute land freely, these residents said that the use certificates did not reflect the actual use of land because a whole system of grassroots land use had developed which made the official allocations, and thus, their certificates highly problematic and inaccurate. Indeed, many grassland scientists and scholars in China have criticized how local citizens use land freely (Ding et al 2002, Li 1999, Liu 1995, Yan 2003, Yu 1995, Zhang 1995). Interestingly, one scholar from a regional university told me that it was "local rights that restrict the [National Grassand] law." "Many areas," said the scholar, "break the law and cannot control use nor management of land." An official from the Xinjiang Animal Husbandry Office (the regional government bureau that allocated land to lower level governments during decollectivization) said that the reform grassland allocation contracts have been "ineffective and have become mere scraps of paper" (chengbao hetong shi yi zhi kongwen). While the household allocations might be "paper agreements," the role of local agencies and agents in determining local orders of land use (their nature often opaque to the state), raises very interesting and nuanced questions about the nature of power relations in land use decision-making and the implications of these power relations for understanding government and the state in ethnic minority areas of China.

The land use situation in minority areas in Altai seems to refer to a complex informal politics between and within pastoral communities and local governments. Based on research conducted by grassland scientists and experts (both international and Chinese), Chinese grassland policy aims to encourage the sustainable use of grassland through the modernization of the traditional nomadic pastoralism of minority peoples, and its transformation into industrial animal husbandry by leasing use rights to individual households and encouraging its fenced enclosure. Grassland policy also encourages grassland improvement, the development of rotational grazing in such enclosures, the monitoring and enforcement of livestock stocking rates, and the formation of grassland conservation areas. Yet the implementation of grassland policy in Chinese minority nationality autonomous regions has been inconsistent (Humphrey and Sneath 1996a; 1996b; 1999). In this article, I discuss how local land use arrangements in Altai, and the informal policy at the local level which supports them, differ from national level scientific and policy initiatives. In the one minority Kazakh area of Altai which I will describe, land use practice is a historically inflected and an improvised affair in which populations of land users operate according to the norms of culturally specific political economic orders. Drawing on the local particularities of northern Xinjiang, I argue that land use arrangements which resulted from the limited implementation of the policy represent a wholly other kind of politics, both an engagement of the area by the central government and its local grassland management institutions, but also a way that the residents of one locality have engaged the state in culturally specific ways.

\footnotetext{
1 Department of Geography \& Anthropology, Eastern Washington University, Cheney, WA 99004, USA. Mzukosky "at" ewu.edu. I would like to thank the enthusiasm, feedback, and support of the following people: Karalygash Altenbek, Christopher Carrico, Stacy Warren, Sydney White, and Emily Yeh. Special thanks for research assistance and permission to Tony Banks from New Zealand AID, Unerkhan Bayan from the Xinjiang College of Animal Husbandry Sciences, and Liu Changping from the Qinghe County People’s Government. Financial support for the research was obtained from the Fulbright-Hays and Wenner Gren Dissertation Research Grant.
} 
The unevenness of the results of Chinese grassland science and policy raises very interesting questions about the nature of governmental power in China. Applying contemporary theory in the ethnography of the state (Das and Poole 2004, Mitchell 1989; 1999; 2000, Taussig 1996) and the anthropology of development (Li 1999, Moore 2005) to data from recent ethnographic fieldwork, this article reflects upon the theoretical problem with understanding grassland use as conforming with the central government's own political economic reasoning with any degree of coherence or consistency. Thus, there are limitations with how we can understand grassland science and policy as government, defined as a center acting on the action of the periphery. In a reflection on this approach from the vantage point of ethnographic fieldwork in Xinjiang, this article documents how grassland policy in China is used symbolically, as in the grassland use certificates above, to render invisible to the center local interests and conflicts and making audible/visible a narrative of a seemingly coherent, consistent, and organized state.

\section{The Literature}

As it attempts to transform the "traditional animal husbandry economy," grassland policy was originally primarily an economic development policy for ethnic minority (often pastoral nomadic) groups in the border regions of China. More recently, the latest published versions of documents like the Revised National Grassland Law have shifted to a sustainable development and environmental conservation mode. This kind of modern economic/environmental policy has as its explicit objective the optimization of the prosperity, order, and power of Chinese polity through the rational control of its subject, through the economic knowledge of animal husbandry, the scientific knowledge of grassland science and conservation, and the development of new kinds of economic and environmental subjectivities. The study of minority nationality politics that revolve around grassland policy can illuminate government in China, particularly the on-going way that diverse subjects and peripheral areas are integrated into a seemingly centralized, multiethnic nation-state. Many ethnographic accounts have highlighted the nuanced and dialectical forms of minority engagement with Chinese governance (Litzinger 1999, Schein 2000). Anthropologist Eric Mueggler (2001) has written that minorities in modern Chinese government have used their distinct cultural resources to engage policies and subject-making in special ways.

Grassland policy is a rich realm through which to explore these issues. An international and crossdisciplinary literature on Chinese grassland policy has grown sigificantly (Goldstein and Beall 1989, Humphrey and Sneath 1996a; 1996b; 1999, Longworth 1990, Longworth and Williamson 1993, Miller 2000, National Research Council 1991, Thwaites et al. 1998) Much of this research has been focused on the perceived problem of grassland degradation and desertification in China, and despite the policy's focus on minority areas, has been disconnected from the broader literature on minorities in China. Some of this research is indeed part of Chinese grassland policy, informing the work of Chinese grassland scientists and non-governmental organizations, and is critically focused on the effectiveness of the state's policy, particularly in terms of grassland conservation, and has criticized Chinese grassland scientists' description of what they call traditional and backward pastoral practices.

Anthropologist Dee Mack Williams (2002) has stepped outside of this genre of research, and highlighted the theoretical importance of the issue by contextualizing the emergence of grassland science in China. Williams has asked important questions about the socially-situated nature of grassland science and policy in Inner Mongolia as knowledge linked to contemporary Chinese and international politicaleconomic formations. One of the objects of Williams' analysis, in his words, is the "vernacular dimensions of scientific knowledge production that enable some groups to exploit others by perpetuating their subjective misrepresentations of nature"(2002:503). Thus, Williams argues that grassland science and knowledge, by placing the blame for grassland degradation on herders and granting the agency for rehabilitation with grassland scientists, function as an ideology to produce and reproduce unequal social relations among the majority Han Chinese, the majority of the educated, urban-based grassland scientists (as well as national and regional level state officials) and poor, rural-dwelling semi-subsistence herders, who are predominately minorities.

Drawing on work by the philosopher Michel Foucault (1991) and anthropologist Arturo Escobar (1995), Williams thus sees grassland science and policy as "tools of social control that impose a rigid order on \{their\} subject populations" which "mak $\{\mathrm{e}\}$ it difficult \{presumably, for their subjects\} to imagine alternative scenarios." In this sense, the Chinese state represents the interests of the dominant Han Chinese majority and an international scientific elite, and is akin to a Marxian view of the function of state, in as much as grassland science comes into being, is supported by the state, and expresses dominant interests. As technologies which organize the space of grassland for increased monitoring and surveillance, as well as their potential capacity to modify the conduct of their subject individuals and populations, grassland policy seems to be appropriate for Foucauldian/Marxian analysis. Williams refers to the ways that these political technologies are framed in terms of science and technology and thus depoliticize a process whereby minority communities are losing control over their spaces and communities to majority Han Chinese and foreign grassland science intervention. This, in Williams' view, represents an extention of state control from outside and then over minority communities, a kind of absolute sovereignty. 
The contrast with the experience of residents in Xinjiang's Altai Mountains is intriguing. Williams also comments on the lack of implementation of many aspects of grassland policy and draws attention to the vocal and active opposition of local residents to it (2002:510). In her work on grassland policy in Tibet, Emily Yeh (2003) notices that the effects of grassland policy are "not limited to those that strengthen and depoliticize state penetration into the lives of its citizens" (2003:521). While grassland enclosure is much more widespread in Inner Mongolia and Tibet, a real lack of implementation of enclosure in Altai is significant and needs to be better understood in relation to the specificity of state and locality relations in the Xinjiang region.

In an article published in Development Policy Review, economist Tony Banks wrote that his goal was explicitly the elucidation of actual land use arrangements and the confluence between state rangeland policy and the land arrangements of pastoral households. His work does not explicitly theorize grassland use and policy in terms of power relations. In describing and theorizing the similarities and differences between policy (and its lack of implementation) and actual, existing land use, Banks wrote that, "past research may have underestimated the influence of embedded social structures and relations in mediating state interventions" (1997b: 295). He saw an essentialized (and ahistorical) Kazakh social structure as withstanding the political-economic reforms of the Maoist collective period and which determine, rather than the objectives of grassland policy, the use of grassland. Indeed, the existing land use patterns were less the product of state intervention, said Banks, than they were of "prevailing patterns of social norms and organization" (1997b: 298). Banks then traces what he sees as the structure of ethnic Kazakh extended kinship groups and their influence in mediating collective and contemporary period land use arrangements.

Interestingly, Banks linked this power to mediate national level initiatives (what he calls statecommunity synergy) to the structure of the state itself and its component institution, the administration system of minority nationality autonomous regions. The study of the autonomous region institutions was an important part of the early literature on minority nationalities; areas with significant numbers of ethnic minorities are given special rights, part of how the earlier state coopted support in border areas (see Dreyer 1976). One of these rights is autonomy from the central government in decision-making and the power to alter or modify national level policies and legal initiatives, the creation of regional by-laws (Mandarin Chinese, xize or literally more fine and detailed regulations). One of the last lines of the National Grassland Law states that, according to "local special characteristics," autonomous regions should create and implement by-laws (M. jiehe ben difangde tedian zhiding shishi xize). "Regional rangeland policy \{or bylaws\}," argued Banks, "have facilitated the widespread persistence of small-group common property arrangements" (1997b: 303).

In my view, the limited implementation of grassland policy in Altai is related to the liberal regional bylaws, but this does not explain the process whereby land has come to be used in the ways in which I will describe, nor the local informal policies that county and township governments use to make sense of these forms of land use. Upon my reading of the regional law and discussion with regional Animal Husbandry Bureau, the real issue in the by-laws was in preventing conflicts among administrative units (like the new villages and townships that emerged in the Reform period) in the division and allocation of collective lands (see Ho 2001); thus, the by-laws state clearly that formal land allocations should not alter the "historical customs" (lishide xiguan) of use of land and the "current state of affairs" (xianzhuang) should not change when conflicts between administrative units over the use of an area of land emerge. This concern indexes an important set of conflicts in land allocations and which had a crucial role in how actual, existing land use would play out. Indeed, when looked at quite closely, there is a complex set of factors which combine to create the context and power relations in which such arrangements are made possible. It is here that I turn to my own experience in ethnographic fieldwork in Altai, and discuss "grassland policy" from one village's experience.

\section{The Research Setting}

My fieldwork was conducted in northern Xinjiang, in a village in the Altai prefecture of the Ili Kazakh Autonomous Region, as well as the prefectural, regional and national capitals. The region is culturally distinct within northwestern China, and is inhabited by pastoral nomadic, minority Kazakh. Kazakh are historically and linguistically connected with the Turks or Tujue (M), the name given by the Chinese to the nomadic peoples who founded an empire stretching from Mongolia to the Black Sea, had tributary relations with China's T'ang Dynasty, and were later incorporated into the Mongol empire or Yuan Dynasty. After the break up of the Mongol empire, the ancestors of today's Kazakh were part of the Golden Horde and the Turkic Kipchak Khanates of the Central Asian steppe. Today's Kazakh, predominately Kirei and Naiman, migrated into the Altai region in the $18^{\text {th }}$ and $19^{\text {th }}$ centuries in response to Russian colonial expansion into the Central Asian steppe.

Altai is the northernmost administrative area on the Chinese side of the Chinese-Mongolian border in Xinjiang. To the north of the research site were the resident's summer pastures (which abutted the international boundary), and just to the east, were the spring and autumn ones. From the site, the ChineseMongolian border was twenty to thirty kilometers northwards. As the headwaters of the region's Wulungu 
River, the Qinghe River begins high up near the border and eventually makes its way through a large valley and a number of villages. The summer and spring/autumn pastures of the village are all up in the mountains, while their winter pastures are down in the Zhunge'er Basin, to the south of the foothills of Altai.

I will relate a number of observations and experiences from fieldwork in one formal administrative village of the valley. The local economy is semi-subsistence and based on grassland animal husbandry. Households raise mutton sheep and cashmere goats, but there are also significant numbers of cattle, horses, and camels; for cash exchange with regional traders, most households sell lamb and goat skins, wool, cashmere, and meat sheep/beef calves, as well as more specialized households who sell camels and horses. They also have small garden plots used to grow root vegetables like carrots and potatoes, and larger wheat and hay fields. The median per capita income of the area was below the Chinese national average, and like minorities in many regions of China, residents considered themselves to be disadvantaged in the local and national political-economy with particular difficulties accessing equal education and non-farm/animal husbandry employment opportunities. Thus, this community is dependent on their livestock for their livelihoods, and their mobile use of grassland pastures is indispensable.

Using a range of traditional social science research methods, I spent five months discussing land use in the region with scholars, scientists, practitioners, and officials at various government levels and ten months living directly with a group of herders at the village level. The village was selected by the county government as it was said to be representative of the "pastoral nomadic" townships and administrative villages of the county. Although I conducted a census, some semi-structured interviews, and participant observation within the residents' village, ${ }^{2}$ I also visited the residents' seasonal pastures for extended periods, twice with nomadic households themselves on seasonal migrations. My fieldwork thus allowed me to directly observe local land use and to engage residents in extended conversations about such use, as well as carry an extended conversation about land use and policy with local government officials, many of whom came and visited me in different fieldwork contexts. ${ }^{3}$

The actual process of research began as a relationship with the Xinjiang Academy of Animal Husbandry Sciences, an agricultural research institute which was engaged with developing grassland policy and had actively been involved in the creation of decollectivization policy (even advising in the development of regional by-laws). Indeed, this is a government research institute under the regional Animal Husbandry Bureau. By affiliating with this institution rather than the social science and ethnographic universities that are more typical for China anthropology research affiliations, I was doing more than simply affiliating and legitimizing my research. I was also engaging in the first steps in researching, gaining relationships that would help me better understand the nature of grassland policy, as scholars and officials understood it. This was an important part of my research, as I spent a lot of time talking with staff about various issues related to the project.

The village has had little implementation of many of the points of grassland policy such as enclosures, stocking rates, or grassland reserves. Local land use appears as a post-Mao era domain in which a number of different interests - associated with both individuals, groups of households, and the local governmenthave negotiated a local order that can only be understood within the context of the rapid political economic change of the reform period. Later, I describe how and why a local county government enables and supports these arrangements through an informal local grassland policy that directly contradicts national policy and the overall implications of these observations for understanding the governmental effects of grassland science and policy in the locality.

\section{Reform land allocations, use arrangements, and livelihood concerns among Altai pastoralists}

At the local level in Altai, there was a very limited implementation of grassland policy initiatives. There were no fenced enclosures, pasture stocking rates listed on the use certificates simply referred to the livestock population of a pasture at the time of decollectivization (and which are not, in any way, based on

2 When I first arrived in the village, most residents had moved to their winter pastures. In the village, many older household members, younger married couples, and young school aged children stayed behind. After a short stay and census work, I visited the winter pastures for a period, before returning to the village to await migration to their spring pastures, where I stayed for much of the season. Later, I moved to their summer and fall pastures. I would try to conduct one to two interviews per day, and spend as much time with a family doing various chores, helping out, and as often, trying to stay out of the way. With a number of my closest acquaintances, I spent extensive time observing and participating in their use of land. I often returned weekly to town and visited township and county officials.

3 Research was conducted at the village level in the Kazakh language and above the village level in Mandarin Chinese. Tatar and Mongol households also spoke Kazakh as there were no autonomous schools for either nationality in the county. While I am proficient in Kazakh, I worked closely with several local bilingual (Kazakh and Mandarin) research assistants in developing village level interviews; I developed my own Mandarin Chinese interviews for work with local officials. Throughout this text, I have denoted Kazakh terms with K. and Mandarin Chinese terms with M. 
ideas about stability or equilibrium), and they had yet to establish any sizable fenced areas of degraded grassland. This was expressed to me by local grassland managers (part of the Grassland Work Station/Grassland Supervision Office of the county Animal Husbandry Bureau), who attributed this to financial concerns, both in terms of inadequate staff, training, and equipment. They expressed a need to conduct more research, develop more projects, and obtain greater funding. Over half of the local government's grassland management bureaucracy were not experts (that is, with formal education/training in a grassland science discipline) but rather were trained as political cadre (having attended the local Chinese Community Party school), and often remarked to me that they had to learn as much about modern grassland science as local herders. More over, they had a limited understanding of exactly how land was being used at the grassroots level. The few staff were engaged in daily office work routines and did not have any on-the-ground interaction with pastoralists; their work was associated primarily with pastoral settlement and artificial grassland projects, both local priorities that trumped natural grassland management work.

In this space of absence, informal arrangements of land use and management had emerged. These arrangements developed after the decollectivization and re-allocation of land to residents in Altai. During the years 1949-1987, land use among pastoral collectives in northwestern China was allocated to groups and used through the collective land ownership structure of the Maoist government. Twenty years ago, as part of Chinese socialist reform, land was decollectivized with the explicit goal to divide and allocate land to individual households as a way to encourage individual initiative and economic growth. The county government, following advice from the Animal Husbandry Bureau, formed a committee of county, township, and village officials (who all said they were not professional political officials or K. maman; they herded household livestock as well as having political responsibilities to the village and township) for division and allocation of grassland (livestock rangeland) and the distribution of use certificates. I spoke with several officials, all ethnic Kazakh, who were involved with the land allocations and the distribution of associated use certificates, and I learned about the distinctive way that grassland was allocated. As we sat with one official and his family taking a break from harvesting potatoes in their household garden plot, he told me about the process of allocation. This was a conversation that I had with other people in the village and which was supported by them.

The official remarked that the nature of pastoralism as production, both as a technology and as a set of social relationships, was taken into account during the allocations. For the allocation of winter pastures (located some 300 kilometers distant from their village in a remote basin region of desert and desert grassland), the committee established groups of eight herder households called otyq, a specialized Kazakh term for cooperative herding groups, and allotted each a particular pasture. These groups were not the same as any during the collective period, but shared form with some of the specialized production brigades of that period. Winter pastures were the only pastures that were surveyed, measured, and mapped, or became an object of those technologies which make clear bounded household allotments possible (see Figure 1). The nature of the winter pastures, a flat area of desert grassland and gebi, played a role in facilitating these surveys and mappings. Usually, these pastures were listed on their use certificates with their popular and common name, such as Balyantas, or literally Strong-stone, referring to one such pasture which was marked by a large stone boulder (K. uba, stone cairns or conical piles of stones used as markers, monuments, or memorials) said to have been placed by a Kazakh ancestor to memorialize the spot of the birth of his child.

Because of the local and particularistic character of these techniques and relations, as well as the embeddedness of local cadre in these relations, the use of land followed existing cultural norms. An elderly man named Berles (84 years old) said that the term otyq in the pre-revolutionary period referred to smaller groups of laborer-herders who would migrate with livestock to more distant winter pastures away from the groups of families who settled together in the mountains for the winter. That is, the concept indexed culturally specific pastoral history. Likewise, the concept of the otyq never made it beyond the committee; neither the Grassland Supervision Office, the government office responsible for implementation and monitoring of adherence to the grassland policy, nor the county government really understood its presence or meaning, as common property allocations. Because each individual household had been allocated a use certificate for the use of a common winter pasture, this office was unclear that there had been eight households who were allocated one single pasture. Many of the staff had not been part of the decollectivization process. From the perspective of the central government, all grassland had been allocated down to the household level, meaning that each household was allocated a pasture; in the Ministry of Agriculture in Beijing, I was told with all certainty that there were no common property arrangements in Xinjiang.

While not the reemergence of older structures, the use of land followed historically and culturally specific patterns. The otyq groups were created to facilitate the use of winter pasture land. As herders used a four week period by horse and camel caravan to migrate to their winter pastures from their autumn ones, no one would make this migration individually. The otyq originally had eight households (anywhere, in my experience, from three to eleven households, depending on size, social relations, and livestock numbers), all from the same production brigade (with exceptions) who were each allocated one winter pasture. They

Journal of Political Ecology Vol. 15, 2008 
were mostly kin. Groups of four households would come together and cooperate to make the winter migration; each year, three households would contribute three young men and three large bags of wheat flour to herd all four households livestock. The three young men would move with the livestock in the day and set up a camp during the evening using the top portion of their yurts without its walls (K. khos). Then, they would spend the winter on their fixed pasture site (see Figure 2). Due to the large areas of desert and desert grassland, it made sense for these herders to cooperate, where one young man could collect snow for the group's water supply (as their were no other ground water sources) while another managed the herd, and yet another rested from staying awake through the night to watch over the livestock; back in the village, the elders played cards, watched their grandchildren and the few milk cows left behind for their use, while younger children went to school.

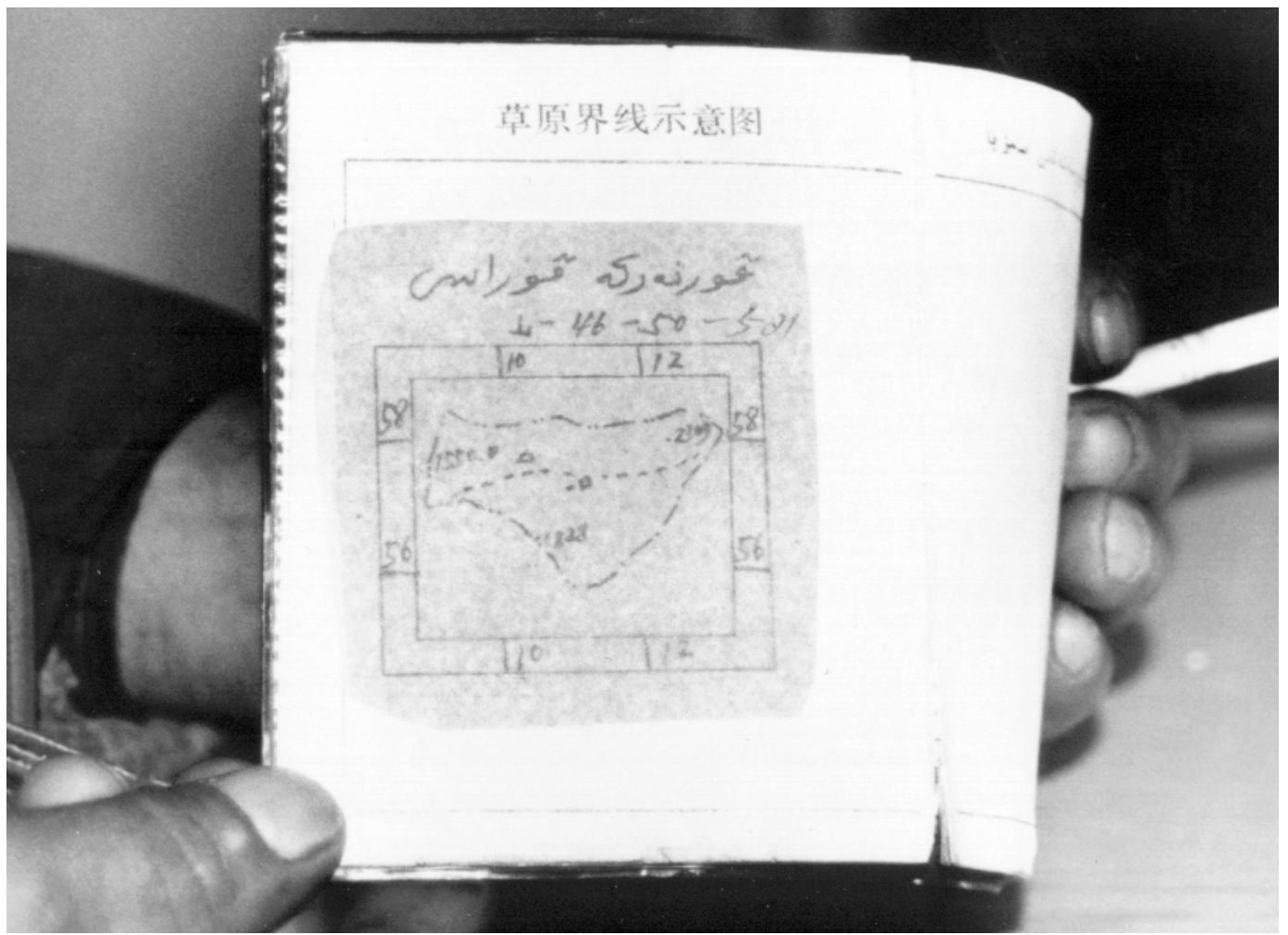

Fig. 1. This is one otyq's grassland boundary map, and is the only one of the residents' seasonal pastures that have been surveyed and mapped. None of the other pastures are depicted spatially in the seasonal pasture use certificate.

The role of new self-understandings and identities that emerged as new social groups and communities replaced older ones are also important for understanding the ways that land was allocated and used. One man told me that they more resembled earlier "tribal" relations then the production work teams did (the unit by which collective grassland was organized), and commented that the term tribe (K: uru) and otyk were synonomous, referring to their often kinship-based, patrilineal relations. This was because individual members of collective entities were not permitted to move between production brigades during the Maoist period (when kin and uru-based identities were discouraged). During reform, these restrictions were lifted and many households moved to be closer with kin. Local households began to understand groups which emerged and replaced collective period arrangements as "tribal," as many consisted of close kin relations. Nevertheless, they were not understood as aul, which now almost always refers to the whole of the settled village or countryside, not the extended kin group. Thus, the use of land was closely related to these new social relations and how local residents understood them and not an essentialized social structure, even if residents tended to frame them as such.

For most other seasonal pastures, officials used the jurt, a Kazakh term that means family or encampment of a household. The jurt is physically represented by a spatial position on a pasture marked by the circular impression (K: dönggelek) left by a family's yurt, an adjacent semi-permanent livestock enclosure (K. qora), and possibly a wooden rack staked to the ground for drying cheese (K. öre). As one 
woman named Baket said, "What was near you, near your jurt, was yours. It's all an issue of distance, \{but not boundaries \}; if an area is far from you then it's not yours, but if it's close than it's yours." That is to

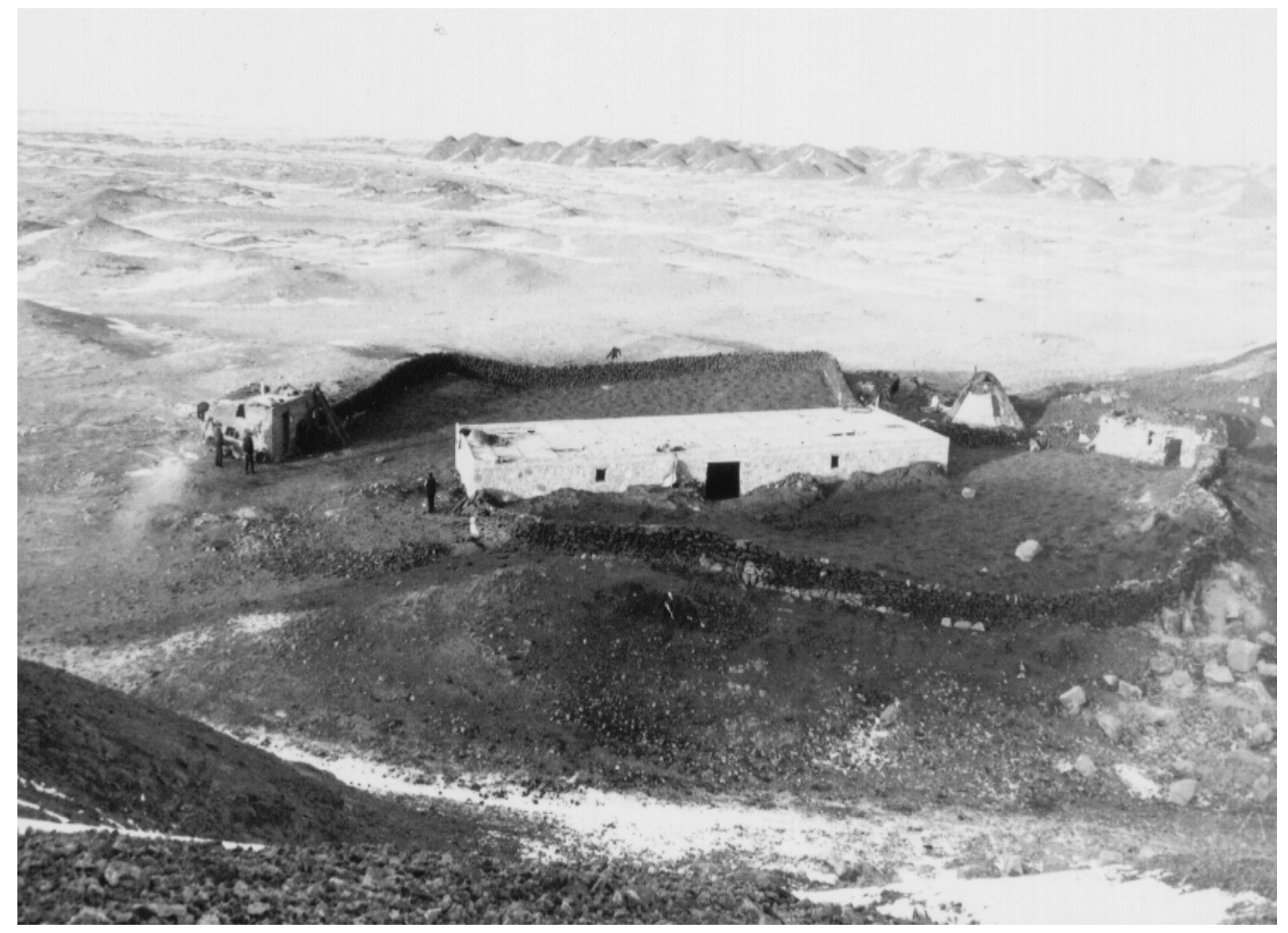

Fig. 2. An otyq winter pasture residence site. In the center is a livestock enclosure that was recently completed by the county government with the assistance of World Bank funds for the Snow Emergency Project and which was designed to alleviate loss of livestock to exposure. To the left and right of the enclosure are two otyq members cement houses, also built with project funds. There is a khos between the enclosure and the house, and another one just outside the frame also to the right. The next year a different set of individuals from the group of households will be here, switching personnel from year to year.

say, they were allocated grassland according to the position or location of that household during the previous collective period when a family herded livestock for the production brigade (see Figure 3). These households' pastures were not always the same as their production brigade or village because the collective leadership had established specialized pastures used for particular breeds of livestock. For example, if a pasture was good for sheep, then more than one specialized sheep herding households of several production brigade might herd there. Today, these seasonal pastures can have individual households from different villages and townships herding their livestock.

Very particularistic and local understandings of land use were used in allocating the pasture use certificates; exclusive household use rights -the stated goal of the surveying and mapping- was never a question in implementation of these pastures. Like property regimes in other socialist and postsocialist contexts (Verdery 2003), this supports the work done by a number of scholars on the "fuzziness" ${ }^{4}$ and "ambiguity" (Ho 2001) of property in post-reform China. In Altai, individual household enclosures did not make "sense" for nomadic pastoral practices, and this was understood by local cadres at the local level (most of whom were Kazakh and many of whom either herded livestock or had experience herding). For these other seasonal pastures as well, groups of households were allocated pastures. These allocations could range from three (a small, steep and rocky valley) to eighty households (a long and broad, lush pasture with many springs), and were thus common property.

4 See the introduction to the special issue of Conservation and Society dedicated to post-socialist property rights by Sturgeon and Sikor 2004. http://www.conservationandsociety.org/sivol-2-1.php 
Not only was the process of decollectivization different (and even opposite) from that envisioned by policymakers, but the actual use of the land following these allocations was different too. Rather than reaching the national objectives of household pastures, land began to be used in ways that fit the shifting social relations of the post-Mao political economy. As the allocation of land was simultaneous with the dismantling of the collective structure of rights and benefits, kin and other extended social networks (particularly in-laws, friends, and neighbors) began to fill in the roles and duties of the former collective apparatus. Moreover, when land was actually used, the arrangements were even more complex and indexed residents new emerging identities (not of certain production brigades, but of new social groupings). If we are to understand grassland policy, this other order of land use needs to be better understood, the rights and obligations as citizens that these individuals have to each other and their social groups, and how this was made meaningful in informal land use management.

An example of this might suffice to demonstrate my meaning. According to grassland use contracts, all of the pasture along several miles of a local river and up to the surrounding river valley's mountain ridges had been formally allocated to four households; the largest parcel and that which was closest to the village was allocated to the former reform period village cadre who had participated in the pasture allocation committee. Yet, when I visited this area, the cadre was using one of his "other" pastures elsewhere. When I visited in middle springtime, I counted no less than twelve households using it. On the eastern edge of a bend in the river, and where another smaller creek met the river's flow, two households had set up their yurts side-by-side. These households were related by marriage. The pasture itself was formally allocated to the brother of the oldest woman of the household. The second household was of a man named Jaqsilik; he was a friend of the first household (who were neighbors in the village) and herded several village households' goats there (and said that his own allocated pasture was good for herding sheep, but not his goats). As he and I sat talking, he told me that other village residents herded their sheep on the pasture which he was formally allocated. These two households worked together, said Jaqsilik, and had a herding routine that incorporated both this pasture, as well as a nearby pasture named Kunde, depending on the spring period. Kunde had been formally allocated to another group of households.

As I walked along the valley, and came up to the next yurt, I was told by this man that he had moved to this position because the pasture he was formally allocated was not very good, and he like herding here

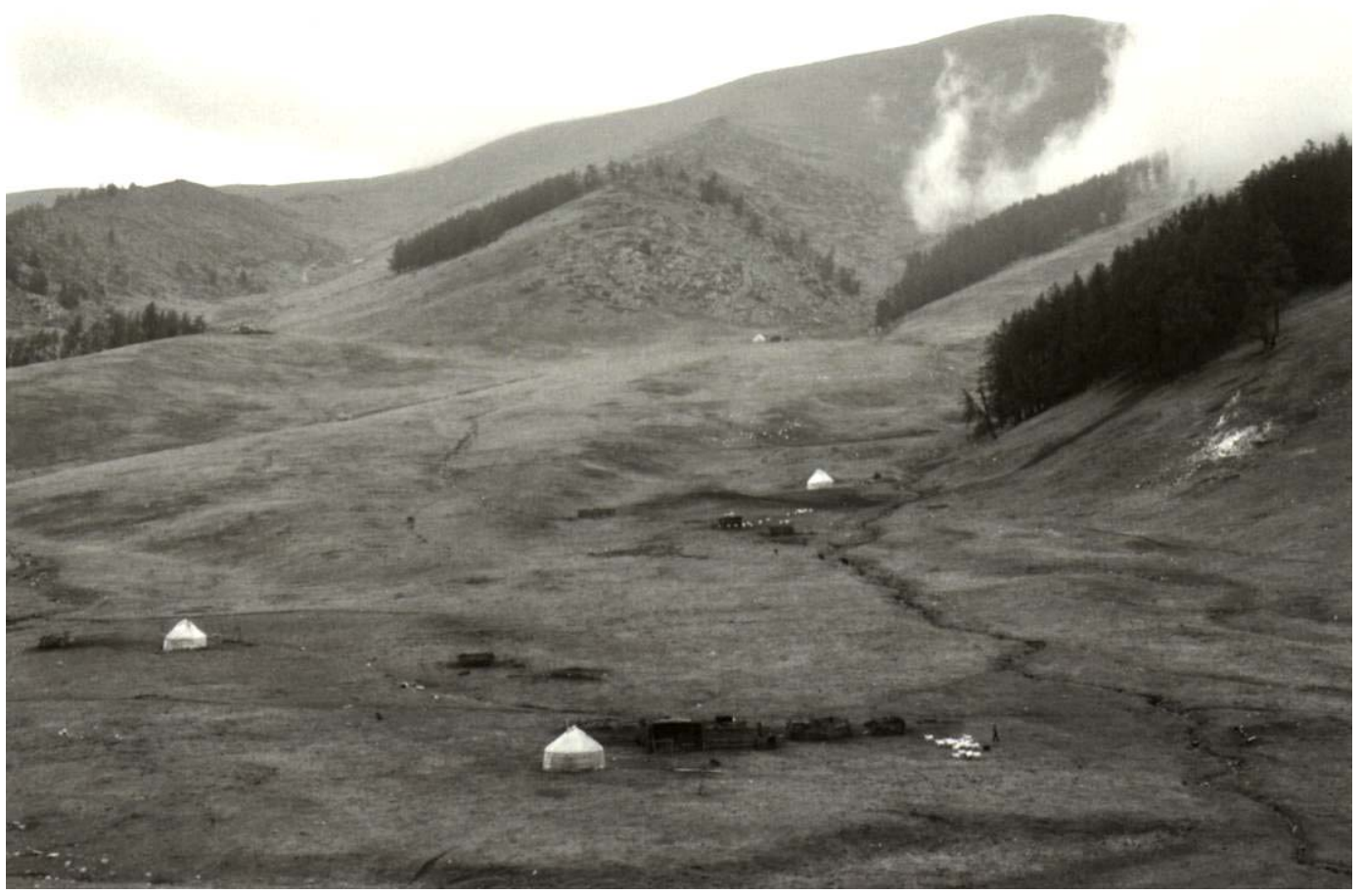

Fig. 3. This is one of the otyk member's summer pasture. The member shares the pasture with over eighty other households. This photograph only shows one area of this large, high altitude valley named Jandaluk. Some households will herd individually, and others pool their livestock into common herding routines, depending on each household's own situation, what households are present, and the relationships between them. 
instead, as it was close to the village and he could engage his village work too. Other households also made this comment. His household had no immediate relationship to any other around him, and there was one other household like him there too. As one got closer to the village, there were a number of yurts who were herding on the formal pasture allocation of a man named Sakan. While Sakan used this pasture (two of his daughters herded here, but slept in the village and his son herded on a more distant pasture, living in the family's yurt), he also was using one of the pastures which had been formally allocated to Muhamet, who herded his small numbers of livestock on Saken's pasture; they had an informal exchange relationship. There was also Jaqsilik's older brother and two other households, all of whom were said to have few livestock. The rest of the households were close siblings or more distant relatives of one of the households who had been formally allocated land. This is a common pasture arrangement, but is completely situational and will not be found in quite this way again, as I saw in subsequent visits during the following two years.

I had many conversations with those who had been officially allotted pasture about why they allowed others to use the pasture they had been formally been allocated. Several people had a hard time understanding the meaning of this question. "Am I not Kazakh?" replied one man (linking these practices more generally with customs and national identity), defining his identity and relationship to his kin and neighbors in terms of allowing access to his pasture. I was told that most people only used it temporarily (as they might use it for only part of a season), that some of the people who used it only had few livestock and so that it was not convenient for them to go to more distant pasture (one of the households had a disabled member) where they had been allocated, and many other reasons. As has been shown for common property regimes elsewhere (McCay and Acheson 1987) there were rules about accessing this pasture: for example, the existing human population, livestock numbers, period of the season, pasture quality, etc and the arrangement had to be temporary, with no establishment of a livestock enclosure or other permanent structures. Most importantly, you would have to have a social relationship with the households using the surrounding pasture.

When asked about why residents used land in quite this way (and presented with the idea of household allotments and enclosures), herders would often say that grassland use followed their custom, even using locally the Mandarin Chinese term fengsu xiguan. This notion of custom has a long history in China, within the older Imperial civilizing project as a space in which localities were able to "engage in distinctive practices...so long as they subscribed to a critical core of Chinese cultural practices" (White 2000:174, Harrell 1995). During the establishment of the People's Republic of China, ideas about the special rights of minorities were based upon the consciousness of difference in customs. In the post-Mao period, this notion of customs among minorities has made a resurgence and been represented in positive ways, particularly those practices deemed able to contribute to the economy and strengthen the social/national order. Indeed, the emergence of powerful ethnic identities in the post-Mao period has been widespread (Gladney 1997). Yet, today, the land use practices of pastoral groups that support subsistence strategies are represented as "backward" practices to be transformed. They are framed as a "traditional economy" to be overcome. It is particularly interesting that local residents frame these practices not in terms of economy -as they are often self-critical as what they see as their backwards animal husbandry- but as a much more generalizable "customs." Indeed, as I began to contemplate this issue, I soon began to feel that applying grassland policy, land use, or other categories to these practices was really a way of disembedding and abstracting one component of a complex social life. By using the Mandarin Chinese term fengsu xiguan, local residents reembedded land use in this broader cultural complex and drew upon the political resources of regional autonomy associated with their identification as ethnic minorities.

Allowing such customs facilitated the kinds of arrangements that fit pastoral herding routines and the kinds of social relations that Kazakh herders found useful at the village level. Like other group activities in Lasta, group grassland use and the sharing of the resources contained on particular pastures functioned to bring households together, and was part of local community identity, transcending various internal economic groups, and thus helping to transcend the conflicts and widespread social stratification that had developed in the community since reform. In this way, I see these arrangements as having an identification effect (see Trouillot 2001) which enables the development of a shared feeling among local actors that they are all share a common livelihood, are all members of the same community, although not necessary equal members of the multi-ethnic People's Republic of China. It is in the importance of potential conflicts that I turn to in the next section to explore their role in the development of the local government's informal and improvised sanctioning of common property arrangements.

I could see this "identification effect" in the way that, upon arrival to their summer pastures and the setting up of their household, family members would pay visits and bring gifts to their neighbors (K: kedry), some of whom they might not have seen during the past year, and reestablish their relationship through tea and discussion. If I asked about a household's relationship to his neighbors on a single pasture, I was almost always confronted with the reply "relative" (K: tyis, common to a number of Turkic languages), and quickly learned that locally the terms of neighbor and relative were synonomous; my close acquaintances would remind me, as a guest from afar, that "a close neighbor is better than a more distant relative" (K. osaqtage tyistan zhakendaga korche arteq). Like other group or communal activities (men's prayer groups, leather working, felt-making or weaving work groups to social events like weddings, 
funerals, and circumcisions), these groups of land users were productive of community social relations. The patterns in social relations that I saw in terms of the use of land were often reproduced in these other related contexts such as groups to collect reeds, medicinal plants, or firewood. As households arranged pasture for their livestock on relatives or neighbors holdings, or made room for their neighbor or kin, they created webs of social relations.

Anthropologist Chris Hann (2003) has used the notion of a "moral economy" for postsocialist land use arrangements. Grassland resources in Lasta are tremendously important in local semi-subsistence pastoralism, as pasture but also as food, medicine, and productive materials that are scattered across the grassland landscape. With the retraction of the collective structure, residents have had to provide for themselves many things which were provided to them by the collective administration. For example, there were areas of wild fruit orchards, edible and medicinal plants, groves of reeds and willows, and pine forest that were accessed in common. After pasture was allocated in Lasta, herders traded positions, shared areas of pasture, and generally, used pastures in ways that were different from the original arrangements on paper, loaning and sharing allocations, combining and dividing pastures, even ignoring formal allotments, as they continued subsistence practices. The land use arrangements were what made possible the existing livelihood practices, both in terms of these material concerns and the social relations needed to utilize them. In this sense, the support for these arrangements were precisely the kind of moral economy that Hann discussed.

Thus, land was allocated in ways related specifically to pastoral nomadic practices, as well as the nature of the different technical requirements for herding on various pastures. Moreover, there actual use diverged from how land was actually allocated, but which better fit local conditions, social relations, and livelihoods, as well as a community morality and identity. There was no sense within the community that the government was trying to implement a grassland policy that did otherwise. The real insight into this local power in land use decision-making emerged in discussions about local conflict over land use and these early allocations with residents and then the local government.

\section{Socialist reform, social stratification, and informal politics at the local county level}

Despite a local moral economy and strong community identity, these arrangements did not serve the interests of everyone in the community equally. In a report provided to me at the Xinjiang regional level, twenty percent of all conflicts during the years immediately following decollectivization between individuals and the government were the product of land tenure disputes (M. jiufen). From my research, these disputes were primarily over the quality of formal land allocations and seem to have been made primarily with marginalized individual households with limited social networks. ${ }^{5}$ Allocations of grassland, like agricultural land, are difficult to distribute fairly due to their very material nature; due to the topographic and seasonal variability of arid grassland, each pasture had advantages and disadvantages for households. Unlike agricultural areas, there were never any periodic re-allocations of pasture. Moreover, there was no particularly random process of allocation, like the random slips of paper that were used to choose individual livestock, even down to factors like sex, age, weight and color in collective livestock allocation. Local residents said this process was random, as slips of paper allowed the allocation of livestock by lot, and thus, particularly good livestock were not concentrated in any particular household. This could not be said for formal grassland management.

While allocations usually followed the jurt, there were a number of exceptional cases of allocations that did not, and hence a household had to move their jurt to use their allocation. One resident said,

Before the reform, we herded riverside at the bottom of the valley, but afterwards and for reasons that we are unsure, that area was given to the Number Two Production Brigade. ${ }^{6}$ Those pastures were very good. The pasture we were given is not good, has no road access, and is higher up on the mountain, and our sheep always move down towards the riverside,

\footnotetext{
5 After having stayed in the community for several months, I was witness to a number of events which reflected conflicts over land use, but none of which was ever expressed directly to me. The first observance of such conflicts was when an acquaintance and I were making lunch in his house and a neighbor came over to threaten him with a formal complaint to the county government about his use of the neighbor's land. After having attended two weddings, one funeral, and circulated houses during the Islamic holiday season and knew most everyone by name, I was struck by the fact that I had never met this individual. He never came to anyone’s house, and as I learned, was not welcome there; I never ascertained the full history of this conflict.

6 In the pre-revolutionary period, there were two groups, one of which dominated the local politics, which used the valley in which the contemporary village community was situated. This group was also an early group to be "pacified," or whom acquiesced to the shift to Chinese Communist Party control in the revolutionary period. While the collective period saw an integration of these two groups, as well as other more distant groups, into the commune system, the group which was dominant during the earlier period was able to retain significant numbers of leadership positions in the collective administration structure. To a lesser extent, this is true today. I am withholding the names of these groups due to their reflection of certain fractures in the community.
} 
towards the better pasture and water. So after returning for a brief period to our older jurt, we came to use our relatives' pasture here [The place the resident referenced was about halfway up the mountainside, and was on the pasture of a different village.]. After staying there and talking to the cadre, our allotment was eventually changed to this position.

In terms of formal allocations, not every household received an "equal" pasture in terms of quality and/or in relationship to their herd composition. When looking at, comparing, and discussing the formal allocations with residents, I came to better understand how local legacies and power relations clearly had worked themselves out in the process. From my discussions with households, I think the above example demonstrates another principle in the ways that land was allocated and how it is used today. That is, while national policymakers may have had objectives of increasing economic growth by promoting household enclosures, local individuals and groups used grassland decollectivization to pursue their own specific interests in obtaining key parcels of land.

In discussing grassland decollectivization with the former committee members, I was able to better understand the historical process of implementation, but it was only after living in the village and getting to know the way certain pastures related to certain of village cleavages that I learned about how politics within the older collective production team played themselves out within grassland decollectivization. For example, one lineage, a leading social group or clan (K. uru) in the pre-revolutionary context in the county, ${ }^{7}$ had been brought disproportionately into the new Maoist state as cadre and leaders, and emerged equally well positioned in the grassland decollectivization process, having been self-allocated some of the finest village pastures. From conversations with numerous residents, I determined that there was favoritism in allocations, although subtle. This favoritism in land allocations was difficult to research, and was a subject that I only breached indirectly with residents. This finding supports work by other scholars that have shown how hierarchies in the socialist period affected the development of social strata in the reform period, and how socialist period officials sometimes, but not always, used their position to their advantage (Unger 1998, see Watson et al., Yan 1992). The banned text Survey of Chinese Peasants by Chen Guidi and Wu Chuntao (2004) was precisely about the ways that the weakening of the reform state, by preventing greater centralized control, allowed the self-enrichment of rural officials. Unfortunately, there were only a few opportunities for me to see and hear these conflicts surface into the open, so strong were local popular ideas of reciprocity and unity. Yet, as a witness to several of these disputes, I came to understand that informal land use arrangement was also a complex negotiation of the interests of different village subgroups.

The existing land use situation, while allowing for a more egalitarian and equitable distribution of resources, smoothed over these potential inter and intra village disputes and conflicts. In the case above, the move from the older jurt drew attention to the decision-making of local cadre, while the move and the later decision of the cadre to "allow" their household to use the new area eased the conflict. Indeed, the existing group access to pasture in general was based on negotiations and compromises between users and through which most of the interests of those households who were re-allocated more marginal pastures were being met. Local policy was important in easing and resolving these conflicts.

That specific interests of powerful local officials and interest groups can be seen to have trumped the objectives of experts gets right to the heart of my argument about how we understand the state effects of grassland science and policy in China. The Grassland Supervision Office was established to monitor adherence to the national policy, but has never attempted to change existing allocations or use. That so many conflicts emerged over land allocations in the early reform period - that certain individuals questioned the decisions made by local cadre in allocating land, created a kind of anxiety among the local government, that favoritism might surface into open dispute about the disinterested nature of local government. Several scholars made this observation directly to me. One official from the county Animal Husbandry Bureau said that had they "formally tried to create boundaries and divide pastures clearly, there would be an enormous amount of contestation." While conflict between individuals would have increased, I believe that conflict between cadre and locals was a central fear in following the "common use" policy.

In discussing this issue with village residents, I was told about a conflict that had emerged during the allocations between them and another village; the other village was agricultural and had only herded a few draught animals, but in allocating land, they were given the whole of the pasture because they had a close "relation" (K. bailansi) at the county level. The conflict had quickly escalated and individuals from the two villages violently clashed. While an isolated incident may have been easy to manage, the local government was anxious about managing more widespread conflict and this conflict coming to the attention of the regional or even national government. So, the threat of conflict was a motivating force. The sheer difficulty

7 The early period of socialist rangeland reform was based on a policy of ziyou fangmu, or open access herding. This policy was meant to undermine the material basis of what had been termed "nomadic feudalism," where feudal control was based on the nominal collective ownership of areas of pasture but which were in actuality under the control of individual tribal leaders since they privately owned the majority of livestock. 
of resolving conflict through formal channels such as the county courts entailed far more -the collection of evidence and the creation of a case- than the local government felt possible, and so, informal, spontaneous decisions were made at the local level by the county administration, the county head in conjunction with township officials. Indeed, local officials even developed their own informal policy, never formalized into a written document, to deal with this issue. This policy and its impetus is explored below.

\section{"Common use" policy and local government}

In his article entitled "Blurred Boundaries," Arjun Appudurai (1995) argues that anthropologists need to better link the "everyday practices of local bureaucracies and the discursive construction of the state in public culture." In Appudurai's view, everyday discourses of favoritism are a way that the state is discursively constructed and representations of the state produced. When discourses of favoritism are invoked, says Appudurai, we have a window on local notions of right and proper state, right and proper governance. These everyday local practices are, in a sense, one of the ways that representations of the state are made possible. Such everyday practices, embedded in local culture and life, are how certain representations of the state come into being and become hegemonic.

Common property arrangements reflect local conceptions of right and proper state that constrain everyday practices of local bureaucracy. "Land was of such a key importance to the farmer," writes Jonathan Unger, "that any favoritism or corruption in the distribution of the fields would have discredited the new system.... with bitter recriminations and political repercussions for decades to come"(65). Since there was some favoritism in allocations in Altai, land use arrangements cannot simply represent individual or community interests and norms, but the articulation and coalescence of a number of interests among different individuals, groups, and the state. The potential for conflict for local residents to oppose the new order worked in their favor. The local government implemented older ideas about "free herding" and "open access," although today the terms of "common use" (M. gongtong liyong) and "unity" (M. tuanjie) are used. In this process, the local government used socialist language and reaffirmed a commitment to the basic principle of collective ownership, not formal household use rights. In the collective period, one of the central policies was socialist land reform [5], and this reform was framed around the "free herding" or "open access" of pasture land, what attempted to resolve pre-revolutionary land conflicts and gain local support. In situations of conflict over resources, socialistic discourse like "common use," much as in the Maoist period, works to negotiate interests among households who have been re-allocated poorer quality pastures. In the resulting common property arrangements, there is a kind of local consensus of fairness, right and proper, in spite of conflict.

The potential conflicts that might have emerged with a more coercive approach go beyond conflict over favoritism. Besides favoritism, formal allocations of land created a number of contradictions that had to be resolved. Since one had to be married at decollectivization to have been allotted land, there are a number of young married herders who do not have any formal grassland use rights. These households are those who married after the allocations. All of these households are using their parents' pastures, often cooperatively, or are finding ways through the varieties of group tenure that I discussed, to herd their livestock. There is no more land to allocate to them, and the local government does not know how to resolve this situation. Likewise, local agricultural villages located lower down the Lesser Qingil River valley were never allocated enough grassland since they were considered agricultural villages, and only their draught animals were herded on pasture. Yet, almost all of these households now have significant herds of livestock, some as big if not bigger than those of the animal husbandry villages, and use the pastures of villages like Lasta. This was also as true for the conflicts which emerged between herders and those individuals who went to grassland areas to exploit subsurface resources like mica and beral, both found locally. This is also a point of conflict and dispute between these two villages that is handled locally among residents themselves, and in which the government's discourses of "unity" and "common use" are used among herders. I was told explicitly by local government officials, both at the Animal Husbandry bureau and at the township level, that the principles of "unity" and "common use" were to be used in these cases, although each violated regulations within national grassland policy (as well as land management policy).

Thus, the local bureaucracy required spontaneity in responding to these kinds of conflict; they could not follow the grassland policy, in terms of its own objectives. This is true not only for the ways that the official committee decollectivized land and which directly drew upon the norms of pastoralists, but also in the way that the county government followed through with governing those land allocations and the conflicts such allocations produced. I was told directly: "We don't want politics to happen." This was in response to a question about conflict over land by certain individuals. Regarding individual conflicts over land allocations, over resource use, and over citizens without land, the head of the Animal Husbandry Bureau, what one might call an official rather than simply a grassland technician or scientist, said, 
That is their [the individual pastoralists] problem. We can't resolve this contradiction for them; they have to resolve it for themselves. We don't want the issue politicized. We want them to cooperate, to unite. So now, yes, it's a kind of iron rice bowl.

The notion of "they have to resolve it themselves" is closely related to the post-Mao shift in government, as the state withdraws from many of its earlier roles, and through which the burden of governing is shifted onto communities themselves. Using statements about how local residents need to "resolve these problems for themselves," local officials are seen to have withdrawn from government, despite drawing on older socialist logics and vocabularies.

The concept of "iron rice bowl," used above, refers to the concept of "everyone eating out of one big pot," and those collective jobs with guaranteed job security, steady income, and benefits. Indeed, contemporary common property arrangements are sometimes referred to as a "grassland rice bowl," referring to the way that grassland use functions much as government collective benefits during the Maoist period, giving herders livelihood security, income, and benefits. This is quite contrary to the national level market discourses. In this sense, the iron rice bowl is synonomous with "free herding" and "open access," as residents can secure various resources needed for subsistence which are guaranteed by the government by such group forms of land tenure. Moreover, such discourses clearly reflect local senses of entitlement, of a right and proper state.

So, as Peter Ho remarked, local governments deliberately "sustain institutional ambiguity to avoid social conflict" (2001: 401). The government, in terms of managing land use, was actually doing very little to implement household enclosures, maintaining a great deal of ambiguity in property rights. At the same time, the common property arrangements that emerged indexed local "customs," pastoral nomadism and its social relations, and local expectations of fairness and propriety. Those officials responsible for the "common use" policy might be called Janus-faced, as Potter and Potter (1990: 281) describe it, answering both to the norms of local residents, and by allocating individual use certificates to each household, those of the central government as well. By actually allocating use certificates to individual households (which appear in state statistics as household land use- giving the illusion of state rationality and policy order), the local government had appeared to be in accordance with national policy, maneuvered around the constraints of the structures of the central government, and made possible representation the division and allocation of land down to the household level. By consciously not implementing the law as written by policymakers, the county government, and more specifically its elected and appointed cadres, local grassroots cadre negotiate and respond to residents local interests and concerns, as well as the power of local residents to become violent and protest what is perceived to be unfair and improper. Through something as simple as a use certificate, these everyday local practices are, in a sense, one of the ways the representation of a coherent and unitary Chinese state is made possible. These interests, negotiations, and disputes made invisible.

\section{Conclusion: The misleading formalism of state presence}

I would like to return to the question of the use certificates and their "formalism." This issue is particularly important because it sheds light on a theoretical problem related to the "formalism" of modern politics, what has been termed the "magic" of the state (Taussig 1996). I choose the term formalism rather than magic because "form" was a notion that two residents used in discussions with me about grassland policy. The use of "form" also echoes Russian formalism's idea that poetic forms are meaningful ends in and of themselves, not simply communicative of representational or referential meaning. Here I apply their ideas to the use certificates and contemplate "grassland policy as a poetic form as an end in and of itself."

If the policy and use certificates do not index the application of a particular form of reason to the world, a means to an end (and clearly not government), then we might better understand them as a poetic form. At the beginning of the paper, I discussed the remarks of local residents that drew attention to a kind of formalism of grassland politics, the ways the policy and its documentation -use certificates, archives, and office bureaucratic procedures, brings our attention, as scholars more than residents or officials, to how things are being done (i.e. certain objective processes which seem outside the everyday happenings of local life), rather than what is being done, in terms of the actual local use and management of grassland by residents themselves, their willingness to protest unfair allocations, and the negotiated common use which resulted.

I began to see policy as an "imaginary signification," reflecting to a lesser extent new forms of modern government, framed in terms of grassland science and its bureaucracy, than new forms of reflexivity, or ways that social institutions like the local government are reflecting upon and narrating their activities and organization (Castoriadis 1997, and for similar usages, see Anagnost 1997, Mueggler 2001, Rofel 1999). Culturally constructed forms of political rule are scaffolded with liberal economics and scientific knowledge, and these scaffolds give one the sense that they stand apart from the everyday, ordering the world, "the way a map does, as a plan which gives the world a dimension of order" (Mitchell 1990: 570). 
The meaning of the use certificate, since it clearly does not index household usage, is in how it reflects the way government actors narrate their activities. Here certain local actors allocated land in a very interested way, but formalisms like policy and use certificates give the process of politics - its negotiations and disputes - the semblance of modern rationality and order. This gives these actors, and China more generally, the unqualified identity as a disinterested, developmental state with sovereign power, not a constantly negotiated and contingent representation by a diversity of interested actors.

\section{Works Cited}

Anagnost, Ann

1997. National past-times: narrative, representation, and power in modern China. Durham: Duke University Press.

Appudurai, Arjun

1995. "Blurred boundaries: The discourse of corruption, the culture of politics, and the imagination of the state." American Ethnologist 22(2): 375-402.

Banks, Tony

1997a. "Pastoral land tenure reform and resource management in Northern Xinjiang; a new institutional economics perspective." Nomadic Peoples 1(2):55-76.

1997b. "State, community, and common property in Xinjiang: synergy or strife?" Development Policy Review 17(3):293- 313.

2002."Community-Based natural resource management and pastoral tenure among Kazaks in the Tian and Altay Mountains of Xinjiang." Paper presented at the 'Changing Face of Pastoralism in the Hindu Kush Himalayan Tibetan Plateau Highlands' conference, Lhasa, Tibetan Autonomous Region, People's Republic of China May 12-14.

Castoriadis, Cornelius

1998. The imaginary institution of society. Boston: The MIT Press.

Chen Guidi and Wu Chuntao

2004. Zhongguo Nongmin Diaocha. Survey of Chinese Peasants. Beijing: People's Publishing.

Das, Veena and Deborah Poole

2004. "State and its margins: comparative ethnographies." In Anthropology at the Margins. Veena Das and Deborah Poole (eds.). Ithaca: Cornell University Press.

Dreyer, June

1976. China's forty millions: minority nationalities and national integration in the People's Republic of China. Boston: Harvard University Press.

Escobar, Arturo

1995. Encountering development: the making and unmaking of the Third World. Princeton: Princeton University Press.

Foucault, Michel

1991. "Governmentality." In The Foucault effect: studies in governmentality. London: Harvester Wheatsheaf.

Gladney, Dru

1996.Ethnic identity in China: the making of a muslim minority nationality. Wadsworth Publishing.

Goldstein, Melvyn and Cynthia Beall

1989. "Change and continuity in nomadic pastoralism on the Western Tibetan Plateau. Nomadic Peoples 28:105-22.

Hann, Chris

2003. "Introduction: decollectivization and the moral economy." The postsocialist agrarian question: property relations and the rural condition. Munster: Lit Verlug.

Harrell, Stevan

1995. "Introduction: civilizing projects and the reaction to them." In Cultural encounters on China's ethnic frontiers. Harrell, Steven (ed.). Seattle: University of Washington Press.

Ho, Peter

2001. "Who own's China's land? Policies, property rights,and deliberate institutional ambiguity." The China Quarterly 166:394-421. 
Humphrey, Caroline and David Sneath (eds)

1996a. Culture and environment in Inner Asia: Volume 1. The pastoral economy and the environment. Cambridge: The White Horse Press.

1996b. Culture and environment in Inner Asia: society and culture. Cambridge: The White Horse Press.

1999. The end of nomadism: society, state, and environment in Inner Asia. Durham: Duke University Press.

Humphrey, Caroline and Ketherine Verdery

2004. "Introduction." In Property in question: value transformation in the global economy. Berg: Oxford. Li Ping

1999. "Luntan caoyuanfa zhixingzhongde jige wenti." Theorizing problems with the implementation of the National Grassland Law. Xinjiang Animal Husbandry 3:26-27.

Li, Tania

1999 "Compromising power: development, culture and rule in Indonesia." Cultural Anthropology 40(3): 277-309.

Liu Chuanyong

1995. "Jiaqiang caoyuan fazhi jianshe baoxian xumuye jingji da fazhan." Strengthening grassland legal construction to guarantee the development of the animal husbandry economy. Xinjiang Animal Husbandry 15-16.

Litzinger, Ralph

1999. "Reimagining the state in Post-Mao China." In Cultures of insecurity: states, communities, and the production of danger. Jutta Weldes (ed). Minneapolis: University of Minnesota Press.

Longworth, John W. and Gregory J. Williamson

1993. China's pastoral region: sheep and wool, minority nationalities, rangeland degradation, and sustainable development. Wallingford: CAB International.

Luong, Hy Van and Jonathan Unger

1998. "Wealth, power, and poverty in the transition to market economies: The process of socio-economic differentiation in rural China and Vietnam." The China Journal 40: 61-93.

McCay, B.J. and J. A. Acheson (eds)

1987. The question of the commons. Tucson: University of Arizona Press.

Miller, Daniel

1995."Herds on the move: winds of change among pastoralists in the Himalayas and on the Tibetan Plateau." Discussion paper series No. MNR 95/2. Kathmandu: ICIMOD.

Mitchell, Timothy

1989."Everyday metaphors of power." Theory and Society 19:545-577.

1998. Colonising Egypt. London: University of California Press.

1999. "Society, economy, and the state effect." Pages 53-76. In State/Culture: state formation after the cultural turn. Veena Das and Deborah Poole (eds). Ithaca: Cornell University Press.

2002. Rule of experts : Egypt, techo-politics, modernity. Berkeley: University of California Press.

Moore, Donald

2005. Suffering for territory: race, place, and power in Zimbabwe. Durham: Duke University Press.

Mueggler, Eric

2001. The age of wild ghosts. Berkeley: University of California Press.

National Research Council

1991. Grasslands and grassland science in Northern China: a report of the Committee on Scholarly

Communication with the People's Republic of China. National Academies Press.

Potter, Sulamith Heins and Jack M.

1990. China's peasants: the anthropology of a revolution. Cambridge: Cambridge University Press.

Rofel, Lisa

1998. Other modernities: gendered yearnings in China after socialism. Berkeley: University of California Press.

Schein, Louisa

2000. Minority rules: the Miao and the feminine in China's cultural politics. Durham: Duke University Press.

Sturgeon, Janet and Thomas Sikor

2004. Post-socialist property in Asia and Europe: Variations on 'fuzziness'. 2(1):1-17. 
Taussig, Michael

1996. The magic of the state. Routledge.

Thwaites, R., T. de Lacy, Li Yonghong, Liu Xianhua

1998. "Property rights, social change, and grassland degradation in Xilingol Biosphere Reserve, Inner Mongolia, China." Society and Natural Resources 11:319-338.

Trouillot, Michel-Rolph

2001. "The anthropology of the state in the age of globalization." Current Anthropology 42(1).

Watson, James (ed)

1984. Class and social stratification in post-revolution China. NY: Cambridge University Press.

White, Sydney

1998. "State discourses, minority policies, and the politics of identity in the Lijiang Naxi People's Autonomous County." Nationalism and Ethnic Studies 4(1\&2):9-27.

Williams, Dee Mack

1996a. "grassland enclosures: catalyst of land degradation in Inner Mongolia." Human Organization 55(3):307-13.

1996b. "The barbed walls of China: a contemporary grassland drama." Journal of Asian Studies 55 (3): 665-691.

1997. "Patchwork, pastoralists, and perception: dune sand as a valued resource among herders of Inner Mongolia." Human Ecology 25(2):297-317.

2000. "Representations of Nature on the Mongolian steppe: an investigation of scientific knowledge construction" American Anthropologist 102(3):503-519.

2002. Beyond Great Walls: environment, identity, and development on the Chinese grasslands of Inner Mongolia. Stanford: Stanford University Press.

Verdery, Katherine

2003. The vanishing hectare: property and value in postsocialist Transylvania. Ithaca: Cornell University Press.

Yan Dongwei

2003. "Caoyuanfa xiudingde zhuyao neirong." The important content in the Grassland Law Revisions. China Grassland, 9.

Yan Yunxiang

1992. "Impact of rural reform on economic and social stratification in a Chinese village" The Australian Journal of Chinese Affairs 27: 1-23.

Yeh, Emily

2005. "Green governmentality in Western China: 'converting pastures to grasslands'." Nomadic Peoples 9(1): 9-29.

2003. "Tibetan range wars: spatial politics and authority on the grasslands of Amdo." Development and Change. 34(3):1-25.

Yu Zhentian

1995. "Guancha luoshi <<Caoyuanfa $>>$ guanhao, yonghao, kaifa jianshe hao caoyuan." Practical implementation of the "Grassland Law": Good management, good use, open up and construct good grassland. Xinjiang Animal Husbandry 4:27-28. 


\begin{abstract}
This article explores why local pastoral land use arrangements in northwestern China differ from national level grassland policy objectives and initiatives. Drawing on the local particularities of fieldwork in a Chinese ethnic minority region, I argue that the land use arrangements which resulted from the implementation of decollectivization and new grassland management policies represent both an engagement of the minority area by the central government, but also a way that the residents of one locality have engaged the state in culturally specific ways. Applying contemporary theory in the ethnography of the state (Das and Poole 2004, Mitchell 1989; 1999; 2000, Taussig 1996) and the anthropology of development (Li 1999, Moore 2005) to data from recent ethnographic fieldwork, this article reflects upon how documents and practices as well as ideas of grassland policy make possible certain kinds of political symbols which render invisible to the central government local interests and resource conflicts, and thus, a narrative of a seemingly coherent, consistent, and organized state.
\end{abstract}

Key Words: China, grassland policy, ethnic minority, decollectivization

\title{
Resumen
}

Este artículo explora como el uso de pastizales a nivel local en el Noroeste de China difiere de los objetivos de las políticas nacionales para el manejo de los mismos. A partir del trabajo de campo realizado en una región de minoría étnica China, aquí argumento que el uso y manejo de la tierra, producto de la decolectivización y de nuevas políticas de manejo de pastizales, representa un compromiso del gobierno central y una forma en la que residentes locales involucran al Estado de manera culturalmente específica. Basado en teorías sobre la etnografía del Estado (Das and Poole 2004, Mitchell 1989; 1999; 2000, Taussig 1996) y la antropología del desarrollo ( $\mathrm{Li}$ 1999, Moore 2005), este artículo analiza cómo documentos, prácticas, e ideas de políticas de manejo producen símbolos políticos que tornan los intereses locales y los conflictos sobre recursos naturales invisibles ante el Estado, y consecuentemente crean una narrativa que produce un Estado aparentemente coherente, consistente y organizado.

Palabres Claves: China, el manejo de los mismos, minoría étnica, la de-colectivización.

\section{Résumé}

Cet article est une réflexion sur la différence entre l'aménagement des terres pastorales dans le nord-ouest de la Chine et la politique nationale sur un tel aménagement et les projets nationaux dans le domaine. A partir des particularités locales évidentes de ma recherche parmi une minorité ethnique de la région, je propose que l'aménagement lié à la décollectivisations et une nouvelle politique pastorale a produit à la fois un engagement particulier de la minorité par le gouvernement central et une voie spécifique d'engagement avec le gouvernement par la région minoritaire. L'application de la théorie contemporaine de l'ethnographie de l'état (Das et Poole 2004, Mitchell 1989; 1999; 2000, Taussig 1996) et la théorie anthropologique du développement ( $\mathrm{Li}$ 1999, Moore 2005) aux données récentes de la recherche ethnographique, permettent cet article de réfléchir sur l'influence de documents, pratiques et idées sur la création de certains genres de symboles politiques qui rendent invisible au gouvernement central les intérêts locaux et les conflits sur ressources naturelles et, en conséquence, soutiennent une narration d'un état apparemment cohérent, consistent et bien organisé.

Mots clés: la Chine, politique pastorale, minorité ethnique, décollectivisation. 